\title{
ОРГАНІЗАЦІЯ ВИКЛАДАННЯ ГІГІЄНИ ДІТЕЙ ТА ПІДЛІТКІВ СТУДЕНТАМ ПЕДІАТРИЧНОГО І МЕДИКО-ПРОФІЛАКТИЧНОГО ПРОФІЛЮ
}

\author{
Т. О. Перцева, О. А. Шевченко, Н. І. Рублевська, О. П. Штепа, В. В. Свтушенко, \\ В. І. Главацька, Л. В. Григоренко, Ю. С. Крамарьова \\ Д3 “Дніпропетровська медична академія МОЗ Украӥни”
}

\section{ORGANIZATION OF TEACHING HYGIENE FOR CHILDREN AND ADOLESCENTS AMONG STUDENTS OF THE PEDIATRIC AND MEDICAL-PREVENTIVE PROFILE}

\author{
T. O. Pertseva, O. A. Shevchenko, N. I. Rublevska, O. P. Shtepa, V. V. Yevtushenko, \\ V. I. Hlavatska, L. V. Hryhorenko, Yu. S. Kramariova \\ SI "Dnipropetrovsk Medical Academy of MPH of Ukraine"
}

\begin{abstract}
У статті наведені матеріали з організації викладання гігісни з циклу "Гігісна дітей та підлітків" студентам медичних факультетів, які навчаються за спеціальностями "Педіатрія" та "Медико-профілактична справа". Обговорюються особливості навчального процесу з урахуванням сучасних потреб, пов'язаних з реформою системи охорони здоров'я України.

The article contains the materials on the teaching of hygiene at the department of "Hygiene of Children and Adolescents" for Medical School Students who study "Pediatrics", "Prophylactic medicine". The features of the educational process in the connection of the health in Ukraine have been provided.
\end{abstract}

Вступ. Система охорони здоров’я України зазнає зараз докорінної перебудови. Що стосується державної санітарно-епідеміологічної служби, то їі поточне реформування передбачає значне, більш ніж у два рази скорочення чисельності працівників i, власне, кількості самих закладів. Зокрема, у Дніпропетровській області, що є основним місцем працевлаштування випускників медико-профілактичного відділення Д3 “Дніпропетровська медична академія MO3 України”, з 54 нині діючих закладів CЕС невдовзі залишиться тільки 17. Постає питання: а чи своєчасним є розгляд викладання гігієни у медичних "вишах" з такою перспективою подальшого розвитку державних установ гігієнічного профілю? Відповідь є однозначною: так, своєчасним. Як відомо, при скороченні кількості працівників для забезпечення достатнього рівня ефективності будь-якої системи, в тому числі і охорони здоров' я, вихід є один підвищувати їх якість, тобто професійний рівень, підгрунтя якого закладається саме під час навчання. Отже, передбачаючи невдовзі значний відтік зі служби найбільш кваліфікованих фахівців пенсійного віку, профільні гігієнічні кафедри вищих медичних закладів мають зробити все для того, щоб ближчими роками на їх місце прийшли молоді лікарі з міцними знаннями, сучасним світоглядом та необхідними практичними навичками.

Основна частина. Гігієна дітей та підлітків (ГДП) - галузь гігієни, що вивчає проблеми охорони та зміцнення здоров'я підростаючого покоління. Вона розробляє гігієнічні нормативи та вимоги до середовища, що оточує дитину, а також до різних видів іiі діяльності (навчання, праці, відпочинку тощо), обгрунтовує профілактичні заходи для збереження та зміцнення здоров'я дітей (від періоду немовляти до 18 років). У радянський період шкільна гігієна як наука і галузь практичної охорони здоров'я розвинулась до гігієни дітей та підлітків і стала вивчати всі вікові групи дитячого населення, що були залучені до громадських форм виховання та навчання. Остаточно гігієною дітей та підлітків вона стала називатись 3 1954 року.

Сьогодні гігієна дітей та підлітків викладається у складі навчальної дисципліни “Гігієна та екологія" як: 1) окремий модуль навчальної дисципліни "Гігієна та екологія" для студентів медико-профілактичного

(c) Т. О. Перцева, О. А. Шевченко, Н. І. Рублевська та ін. 
профілю; 2) один з декількох змістовних модулів навчальної дисципліни “Гігієна та екологія” для студентів педіатричного та лікувального профілю.

3 введенням з 2011-2012 навчального року кредитно-модульної системи на 6-х курсах медичних факультетів за спеціальністю "Медико-профілактична справа" та "Педіатрія" кількість аудиторних годин, відведених на гігієну дітей та підлітків (ГДП), дещо зросла. Викладання ГДП за спеціальністю 7.110105. “Медико-профілактична справа" здійснюється за кредитно-модульним принципом відповідно до програми навчальної дисципліни "Гігієна та екологія" для студентів ВН3 III-IV рівнів акредитації, затвердженої МОЗУ 1 червня 2009 року [1]. На базі типової програми у березні 2010 року нами була підготовлена та затверджена робоча програма дисципліни, згідно з якою викладання ГдП займає 90 годин, 3 яких: лекцій - 6 годин, практичних занять - 54 години, самостійної роботи студентів - 30 годин. Для викладання дисципліни використовується підручник за редакцією проф. В. І. Берзіня [2], співавторами якого $€$ також співробітники кафедри гігієни та екології Д3 “ДМА”. Підручник є основним, який рекомендовано профільною кафедрою НМУ імені О. О. Богомольця. Враховуючи специфіку викладання дисциплін за кредитно-модульною системою та відносну неповноту нового підручника, кафедрою складено та видано "Учбово-методичний посібник до практичних занять 3 гігієни дітей та підлітків” [3], де студенти окрім традиційних розділів, як-то контрольних питань, переліку основної та додаткової літератури, знань та вмінь, можуть знайти необхідний довідниковий матеріал, тлумачення термінів, фрагменти нормативно-правових документів, зразки та еталони розв'язання ситуаційних задач, графічні алгоритми вирішення лікарем практичних ситуацій тощо. Циклова система навчання з 6-годинними практичними заняттями дозволяє студенту “зануритись” у проблематику ГДП, чому також сприяє оформлення тематичних навчальних кімнат. У 2007 році на кафедрі було створено дві таких кімнати, де встановлені наочні приладдя, навчально-дослідницьке устаткування, а всі найбілыш важливі теми проілюстровані навчальними стендами. Для впровадження актуальних інформаційних технологій у навчальний процес кафедрою створено та підтримується власний сайт http:// gigeco.turist-ua.com/, на який можна потрапити також i через кафедральну сторінку на загальному сайті академії. Дизайн сайту сформовано за принципом окремих фахів до- та післядипломної освіти, відтак студенти медико-профілактичного, педіатричного або лікувального профілю можуть легко знайти тут всю поточну навчальну інформацію, матеріали до практичних занять, розклади, графіки відробок, корисні посилання, бази тестів “Крок-2”, ті ж самі навчально-методичні посібники, матеріали для підготовки до державних іспитів, актуальну базу нормативно-правової літератури та багато іншого.

Реалії сьогодення, зокрема жорстке обмеження аудиторних годин та лекційного курсу на випускаючих гігієнічних кафедрах, змушують віднаходити нові нетрадиційні підходи до організації навчального процесу. Серед таких засобів слід згадати організацію практичних занять на базі діючих дитячих дошкільних закладів м. Дніпропетровська. Адже жодна ситуаційна задача не залишить в пам'яті студента стільки корисної інформації, як самостійне обстеження реального об' єкта з подальшим написанням акта та розробкою профілактичних рекомендацій 3 використанням санітарних норм та правил. Зокрема, нашими робочими програмами для студентів педіатричного та медико-профілактичного профілю передбачено практичні заняття у вигляді санітарного обстеження дитячого садочка, оцінки організації шкільного процесу на базі середньої школи. Самостійна робота студентів у структурі модуля складає близько $33 \%$, а отже, також вимагає достатнього методичного забезпечення. 3 цією метою чотири теми, винесені програмою тільки на самостійне вивчення, знайшли своє відображення у навчально-методичному посібнику. За необхідністю теми СРС супроводжуються також додатковими навчальними матеріалами для полегшення їх засвоєння студентами. Оцінювання якості підготовки за темами СРС здійснюється традиційно під час проведення підсумкового модульного контролю, де передбачено як теоретичні питання та тестові завдання за цими темами, так і контроль оволодіння практичними навичками та вміннями, зокрема, розв'язання ситуаційних задач, інструментальні дослідження.

Аудиторні заняття за їх організацією є практичними, на кожному з них студенти можуть виконувати такі види діяльності:

- дослідження факторів навколишнього середовища, соціально-гігієнічних чинників та умов навчання, виховання та їх вплив на формування показників здоров'я дітей та підлітків у сучасних дошкільних та загальноосвітніх закладах;

- підготовка гігієнічних висновків за проектами будівництва, конкретними практичними ситуаціями та розробка профілактичних заходів; 
- розв'язання ситуаційних задач, формування практичних навичок користування нормативно-правовою документацією.

Останнє є доволі специфічною формою роботи, яка потребує достатньої кількості нормативно-правових документів, що використовуються у роботі практичними лікарями-гігієністами. При вивченні курсу ГДП студенти мають навчитись користуватись санітарними нормами та правилами, державними будівельними нормами, методичними рекомендаціями тощо (загалом при вивченні модуля використовується близько 15 нормативних документів), які є у достатній кількості екземплярів для індивідуальної практичної роботи кожного студента. На сайті кафедри також $є$ окремий розділ “Нормативна документація”, де ми розмістили у вільному доступі всі актуальні нормативно-правові документи, в тому числі для поглибленого вивчення окремих тем, написання рефератів, виконання індивідуальної дослідницької роботи, що дає можливість студенту отримати додаткові бали до рейтингу.

Під час проходження модуля студенти ведуть протоколи практичних занять, де зазначають тему, принцип методу дослідження, його результати, формулюють висновки та з посиланням на відповідні розділи нормативних актів та надають рекомендації профілактичного характеру. Вхідний контроль підготовки здійснюється за допомогою набору тестів, письмового або усного опитування за питаннями для самостійної підготовки з посібника для практичних занять. При визначенні підсумкової оцінки за тему викладач обов'язково враховує також рівень виконання студентом практичних завдань, оформлення протоколу, повноту та якість гігієнічних висновків, вміння користуватись нормативними документами.

Підсумковий модульний контроль, порядок якого ретельно розписаний у студентському методичному посібнику, включає чотири етапи, за кожен з яких студент може отримати від 12 до 20 балів: тестові завдання (варіанти по 40 тестів з бази “Крок-2”); теоретичне письмове питання; вирішення ситуаційної задачі з написанням висновку; виконання практичної навички (з переліку для підготовки до держіспиту).

Свої особливості має викладання курсу ГДП для студентів педіатричного профілю. Модуль "Гігієна та екологія" містить тут сорок аудиторних годин -4 години лекційних та 36 годин практичних занять. Він має чотири змістовних модулі - окрім власне модуля ГДП також модулі “Гігієна комунальна", “Гігієна харчування" та "Гігієна праці".
Однак, враховуючи пріоритетність для майбутніх педіатрів питань, пов'язаних саме з гігієною дітей та підлітків, переважна кількість тем модуля, в тому числі з суміжних гігієнічних дисциплін, так чи інакше відображає особливості санітарно-гігієнічного нагляду у дитячих дошкільних та загальноосвітніх закладах. Наприклад, тема з гігієни харчування звучить як "Методика оцінки адекватності харчування організованих дитячих колективів за меню-розкладкою. Методика оцінки шкільного сніданку", тема з гігієни праці звучить як "Гігієнічні основи трудової діяльності, методика проведення профвідбору та профорієнтації. Роль лікаря-педіатра та лікаря підліткового кабінету в організації профорієнтаційної роботи”. Для студентівпедіатрів кафедрою також розроблений та виданий “Навчально-методичний посібник до практичних занять 3 гігієни та екологіі”' [4]. Всі заняття є практичними з обов' язковим оформленням протоколів. При викладанні окремих тем викладачі приділяють білыше уваги на засвоєння студентами конкретних методик вивчення фізичного розвитку дитини, оцінці режиму навчання та харчування, організації режиму дня, особливостям фізичного виховання, аналізу показників здоров'я дитячих колективів, тобто тим навичкам, які будуть корисні саме лікарю-педіатру, шкільному лікарю, лікарю дошкільних дитячих закладів. Тут ми не робимо акцент на поглиблене вивчення санітарних правил та на методиці санітарного нагляду, а намагаємося прищепити студентам частку гігієнічного мислення та розвинути в них санітарно-просвітницькі навички. Теми практичних занять мають 2, 3 або 4 аудиторних години, що дозволяє компонувати окремі змістовні модулі впродовж повного навчального дня (3 теми по 2 години або дві теми по 3 чи 4 і 2 години). Поточний контроль, оцінка одержаних знань та навичок, організація самостійної роботи, а також методика проведення підсумкового модульного контролю принципово не відрізняються від таких на медико-профілактичному відділенні.

Аналіз, проведений нами за результатами державних іспитів 2010-2011 навчального року, свідчить, що студенти медико-профілактичного та педіатричного профілю відносно краще розв' язують задачі саме 3 розділу ГДП, де середній бал є вищим, ніж з інших гігієнічних дисциплін, на 0,2-0,3. Але це не може заспокоювати, оскільки є питання, над якими ще треба працювати, зокрема: оновити та розширити матеріальну базу для проведення практичних занять на сучасному рівні; придбати в достатній кількості альбоми проектів сучасних дитячих освітніх установ; адаптувати змістовну частину навчального процесу 
та лекційного курсу з ГДП до реалій реформованої системи охорони здоров'я з урахуванням кваліфікаційних вимог до лікарів сімейної медицини; розширити практику проведення практичних занять на реальних об’єктах санітарно-епідеміологічного нагляду; продовжити практику створення навчальних посібників у вигляді тематичних монографій, методичних рекомендацій, відеофільмів. В цьому напрямку співробітниками кафедри та за їх участю видано низку робіт 3 актуальних проблем гігієни дітей та підлітків, в тому числі:

1) Методичні рекомендації МОЗ України “Антропометричні параметри, шкали регресії для оцінки фізичного розвитку дошкільнят міст Дніпропетровської області” (Київ, 2010 р.);

2) Методичні рекомендації МОЗ України “Соціально-гігієнічний моніторинг здоров’ я школярів та їх навчального середовища" (Донецьк, 2007 р.);

3) Методичні рекомендації МО3 України “Оцінка фізичного розвитку в системі соціально-гігієнічного

\section{Лiтература}

1. Гігієна та екологія. Програма навчальної дисципліни для студентів 6-х курсів вищих медичних закладів освіти України III-IV рівня акредитації, спеціальність 7.110105“Медико-профілактична справа". -К., 2009. - 120 с.

2. Гігієна дітей та підлітків : підручник / за ред. чл.-кор. АПН України, д.м.н., проф. В. І. Берзіня. - К. : Видавничий дім “Асканія", 2008.-303 с.

3. Буряк Л. І. Учбово-методичний посібник до практич- моніторингу здоров'я дитячого населення" (Київ, 2007 p.);

4) “Диетология в терминах, таблицах и тестах" (Донецк, 2007 г.);

5) монографія "Проблеми та перспективи моніторингу якості життя підлітків” (Дніпропетровськ, 2008 р.);

6) “Гігієнічний українсько-російсько-англійський глосарій” (Донецьк, 2007 р.);

7) монографія “Екологія та здоров'я дитячого населення: фактори ризику та епідеміологія” (Дніпропетровськ, 2010 р.);

8) навчальний посібник “Екопедіатрія” (Дніпропетровськ, 2011 р.).

Висновок. Викладання гігієни дітей та підлітків студентам медико-профілактичного та педіатричного профілю на випускаючій кафедрі гігієни та екології найближчим часом має бути організовано таким чином, щоб максимально урахувати потреби, пов’язані з комплексною реформою системи охорони здоров’я України.

них занять з гігієни дітей та підлітків для студентів VI курсу медичного факультету за спеціальністю “Медико-профілактична справа" / Л. І. Буряк, С. А. Щудро. - Дніпропетровськ, 2011.-166 с.

4. Навчально-методичний посібник до практичних занять 3 “Гігієни та екології” для студентів VI курсу медичного факультету за спеціальністю “Педіатрія” / [О.А.Шевченко, Н. І. Рублевська, Л. І. Буряк та ін.]. - Дніпропетровськ, 2011.-107 с. 